Turyzm 2020, 30/2

\title{
MAGISTER ELŻBIETA PARADOWSKA - SEKRETARZ I REDAKTOR JĘZYKOWY CZASOPISMA „TURYZM/TOURISM” W LATACH 1985-2020
}

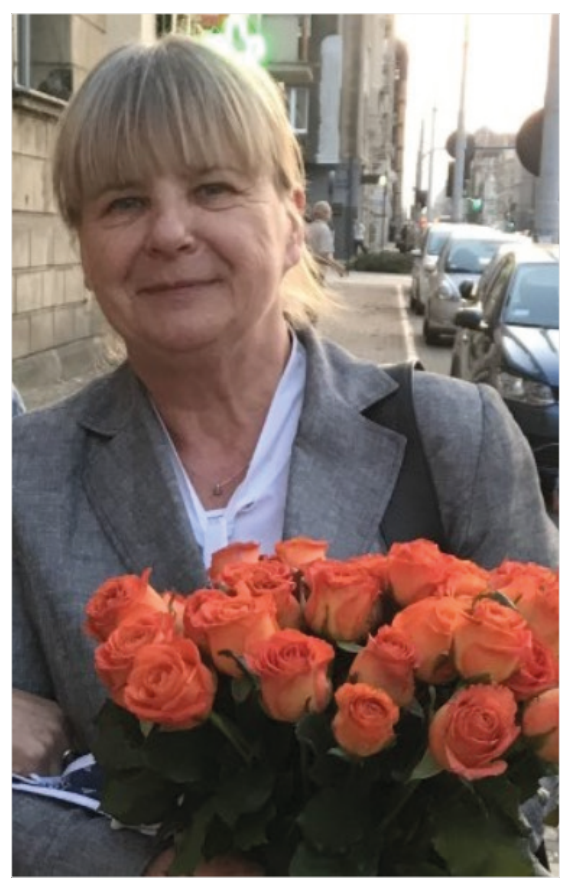

Magister Elżbieta Paradowska przez 35 lat była związana zawodowo $\mathrm{z}$ pracą $\mathrm{w}$ redakcji czasopisma naukowego „Turyzm/Tourism”. Po ukończeniu w 1981 r. studiów na kierunku geograficznym podjęła pracę w Instytucie Geografii Ekonomicznej i Organizacji Przestrzeni na ówczesnym Wydziale Biologii i Nauk o Ziemi Uniwersytetu Łódzkiego. Do obowiązków mgr Paradowskiej należały w tym czasie m.in.: zajmowanie się sprawami administracyjnymi oraz dydaktycznymi działającego od 1977 r. Podyplomowego Studium Turystyki (kierownik: dr Elżbieta Dziegieć), organizacja i prowadzenie biblioteki publikacji turystycznych w Zakładzie Geografii Miast i Turyzmu (kierownik: prof. Stanisław Liszewski), a także redakcja i edycja tekstów naukowych we współpracy z Wydawnictwem Uniwersytetu Łódzkiego.
W chwili utworzenia w 1985 r. czasopisma ,Turyzm” (początkowo w ramach serii "Acta Universitatis Lodziensis") mgr Paradowska pełniła obowiązki nieformalnego sekretarza redakcji, składającej się wówczas z dwóch osób - prof. S. Liszewskiego, który był założycielem i redaktorem czasopisma, i dr E. Dziegieć - sekretarza naukowego. Oficjalnie Elżbieta Paradowska została powołana na stanowisko sekretarza „Turyzmu” w 1990 r. i sprawowała tę funkcję do 2015 r. W tym okresie ukazało się 48 zeszytów czasopisma; kilka z nich było podwójnych, a ok. 20 - dwujęzycznych. Do obowiązków sekretarza redakcji należało na początku m.in. listowne lub telefoniczne kontaktowanie się z autorami, recenzentami i łłumaczami, co bardzo wydłużało proces publikacji, oraz organizowanie posiedzeń redakcji i czynne uczestnictwo w nich. Sukcesywne wdrażanie 
przez mgr Paradowską nowych technologii edytorskich (przede wszystkim komputerowych) i komunikacyjnych (Internet) pozwalało systematycznie skracać proces wydawniczy.

Wyniesione $\mathrm{z}$ domu rodzinnego zamiłowanie do geografii, literatury pięknej oraz języka polskiego zaowocowało zgodą Wydawnictwa Uniwersytetu Łódzkiego, by mgr Paradowska od 1998 r. zaczęła dodatkowo pracować jako redaktor językowy. Zajmowała się adiustacją nadsyłanych artykułów oraz składem komputerowym zatwierdzonych po korekcie WUŁ materiałów, zarówno w języku polskim, jak i angielskim. Ta intensywna praca na rzecz czasopisma naukowego „Turyzm/ Tourism", wykonywana przez mgr Elżbietę Paradowską z dużym zaangażowaniem, trwała nieprzerwanie 35 lat.

Oprócz przygotowywania do druku tego czasopisma mgr Paradowska redagowała i składała serie monograficzne publikowane przez Instytut Geografii Miast i Turyzmu, zatytułowane Konwersatorium Wiedzy o Mieście (obecnie czasopismo; 30 tomów od 1996 r.) oraz Warsztaty z Geografii Turyzmu (9 tomów od 2011 r.). Ważną częścią Jej pracy w Instytucie Geografii Miast i Turyzmu WNG UŁ było opracowywanie publikacji związanych z awansami naukowymi zatrudnionych tam osób. W ramach tych obowiązków przygotowała do druku 12 doktoratów opublikowanych w serii Łódzkiego Towarzystwa Naukowego pt. Szlakami Nauki, osiem habilitacji oraz dwie tzw. książki profesorskie wydane przez Wydawnictwo UŁ. W trakcie współpracy z ŁTN redagowała także liczne opracowania należące do dwóch serii wydawniczych (Sylwetki Łódzkich Uczonych oraz Moja Droga do Nauki).

Magister Paradowska miała ponadto swój udział w przygotowywaniu monografii wieloautorskich (Łódź. Monografia miasta w języku polskim i angielskim, Monografia województwa łódzkiego), w tym pokonferencyjnych (np. Kultura i turystyka - pięć tomów) oraz będą- cych wynikami grantów naukowych, zrealizowanych przez badaczy związanych z Instytutem (np. Możliwości i kierunki rozwoju turystyki w dolinie Odry), a także podręczników akademickich (Geografia urbanistyczna - dwa wydania, w tym jedno Wydawnictwa Naukowego PWN; Statystyka - podręcznik dla studentów turystyki i rekreacji), dwóch tomów księgi jubileuszowej z okazji 70-lecia urodzin prof. Stanisława Liszewskiego, obszernych publikacji bibliograficznych dotyczacych geografii osadnictwa, opracowań strategicznych (np. Strategia rozwoju turystyki w Łodzi) czy raportów $\mathrm{z}$ badań nad ruchem turystycznym w Łodzi i województwie łódzkim, sygnowanych przez Regionalną Organizację Turystyczną Województwa Łódzkiego. Kilkakrotnie przygotowywała publikacje firmowane przez Polskie Towarzystwo Turystyczno-Krajoznawcze (m.in. Szlaki turystyczne. Od pomystu do realizacji).

Podczas swojej pracy zawodowej Elżbieta Paradowska brała udział w powstaniu ponad 250 publikacji, nie tylko czasopism naukowych, monografii i serii wydawniczych, ale także podręczników, raportów czy opracowań popularnonaukowych oraz innych prac ogłaszanych drukiem przez rodzimy Instytut.

Praca mgr Paradowskiej na rzecz Instytutu Geografii Miast i Turyzmu, w szczególności w ramach działalności Kolegium Redakcyjnego czasopisma „Turyzm/ Tourism", jest nie do przecenienia. Zaangażowanie Elżbiety Paradowskiej, Jej profesjonalizm, oddanie Instytutowi i uczelni, koleżeńskość i gotowość niesienia pomocy w różnych przedsięwzięciach podejmowanych w Instytucie mogą być wzorem dla młodszych adeptów pracy naukowej i organizacyjno-administracyjnej.

Magister Elżbieta Paradowska jest jednym z filarów czasopisma „Turyzm/Tourism”, którego funkcjonowanie już na zawsze będzie się kojarzyło z Jej osobą. Serdecznie dziękujemy za wszystkie lata poświęcone czasopismu, Instytutowi Geografii Miast i Turyzmu oraz Uniwersytetowi Łódzkiemu. 